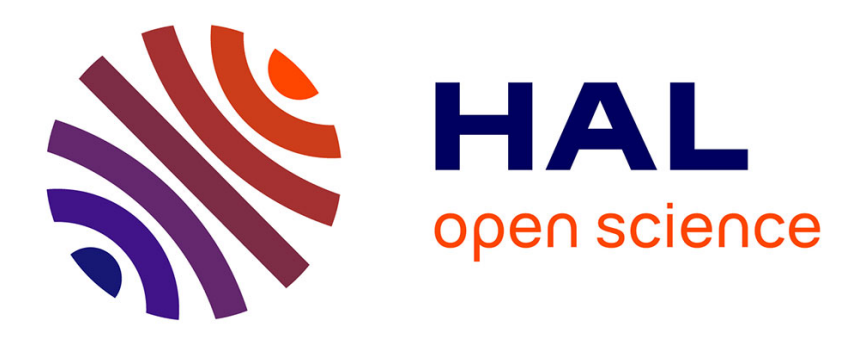

\title{
Simulation of the dynamic organization of dislocation structures
}

\author{
J. Lépinoux, L.P. Kubin
}

\section{To cite this version:}

J. Lépinoux, L.P. Kubin. Simulation of the dynamic organization of dislocation structures. Revue de Physique Appliquée, 1988, 23 (4), pp.699-699. 10.1051/rphysap:01988002304069900 . jpa-00245855

\section{HAL Id: jpa-00245855 https://hal.science/jpa-00245855}

Submitted on 1 Jan 1988

HAL is a multi-disciplinary open access archive for the deposit and dissemination of scientific research documents, whether they are published or not. The documents may come from teaching and research institutions in France or abroad, or from public or private research centers.
L'archive ouverte pluridisciplinaire HAL, est destinée au dépôt et à la diffusion de documents scientifiques de niveau recherche, publiés ou non, émanant des établissements d'enseignement et de recherche français ou étrangers, des laboratoires publics ou privés. 


\section{SIMULATION OF THE DYNAMIC ORGANIZATION OF DISLOCATION STRUCTURES}

\section{J. Lépinoux and L.P. Kubin}

Laboratoire de Métallurgie Physique (UA 131 CNRS), Faculté des Sciences, 40 Av. du Recteur Pineau, 86022, Poitiers Cedex, France

The dislocation structures formed in metals during monotonic or cyclic plastic straining usually build up characteristic bi- or tridimensional patterns: walls, veins, cells...Long range elastic interactions between dislocations are responsible for the occurrence of such nonuniform and organized structures. Two competing factors control these collective effects: when recovery (by cross-slip and/or climb) is effective, dense dislocation arrays tend to form stable structures which minimize their total energy. Kinetic effects,

i.e. the continuous production and storage of dislocations, permanently counteract the tendency to form ordered structures through recovery.

However, dynamic effects can also result in selforganization. This is well-known from studies on various non linear, dissipative systems far from thermodynamic equilibrium (e.g. many chemical or hydrodynamic systems).

In the present study we propose an approach by simulation which incorporates all these energetic and dynamic aspects. The technique used is that of cellular automata. In such simulations, space and time are discretized and physical quantities take on a finite set of discrete values on each site or cell. A cellular automaton evolves by discrete time steps, the values of the variables at each site being affected by the values of the variables in its neighbourhood at the previous time step. The variables at each site are updated simultaneously according to a definite set of deterministic rules.

This technique was adapted to the study of dislocation structures by introducing a small number of rules which govern individual dislocation behavior, that is: their mobility by glide, cross-slip or climb, under the influence of an applied stress and of long range interaction stresses, their multiplication and their annihilation.

Several situations were examined : the formation of Persistent Slip Bands in fatigue, the formation of dislocation walls in creep conditions (Fig.l) and the evolution of internal stresses, the discrete structure of slip (Fig.2) and slip propagation in a Lüders'-like fashion.

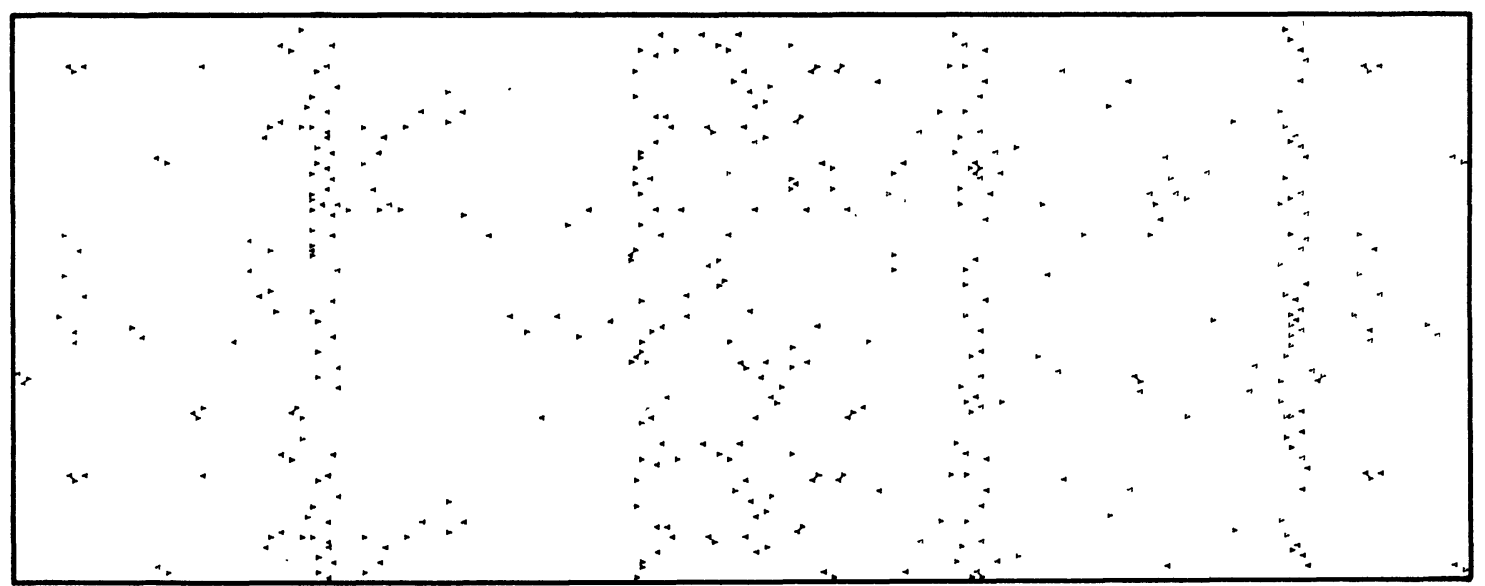

Fig. 1. Edge dislocations. A regular structure of walls and channels is obtained after 800 steps of monotonic deformation under a constant applied stress (initial confiquration: random).

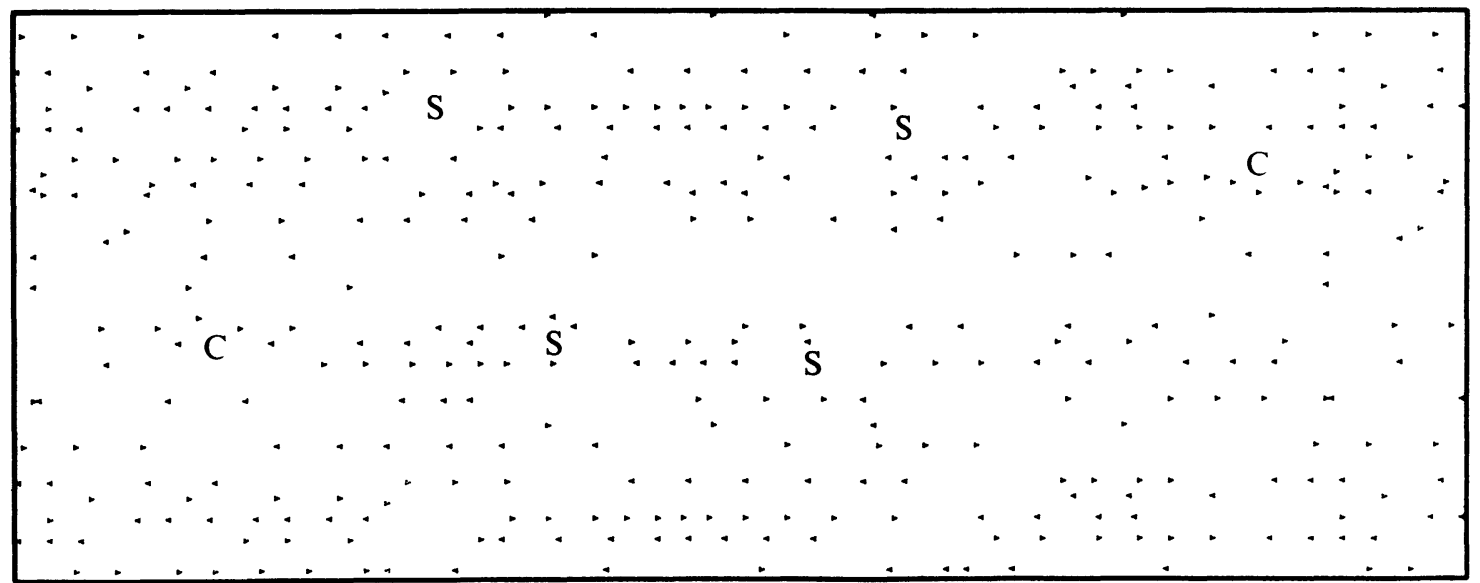

Fig. 2. Screw dislocations. Monotonic deformation under a constant applied stress (200 steps). Dynamic pile-ups, centered at "sources" ( $\mathrm{S})$, interact with pile-ups of opposite sign. This leads to cross-slip events (C). 